\title{
Photobacterium lutimaris sp. nov., isolated from a tidal flat sediment in Korea
}

Correspondence

Jung-Hoon Yoon

jhyoon@kribb.re.kr

\author{
Seo-Youn Jung, Yong-Taek Jung, Tae-Kwang Oh and Jung-Hoon Yoon
}

Korea Research Institute of Bioscience and Biotechnology (KRIBB), PO Box 115, Yusong,

Taejon, South Korea

\begin{abstract}
A Gram-negative, motile, pale-yellow-pigmented, oval-shaped bacterial strain, DF- $42^{\top}$, was isolated from a tidal flat sediment in Korea. Strain DF- $42^{\top}$ grew optimally at $25-30{ }^{\circ} \mathrm{C}$ and in the presence of $2-3 \%(\mathrm{w} / \mathrm{v}) \mathrm{NaCl}$. It contained $\mathrm{Q}-8$ as the predominant ubiquinone and $\mathrm{C}_{16: 0}$, $\mathrm{C}_{18: 1} \omega 7 \mathrm{c}$ and summed feature $3\left(\mathrm{C}_{16: 1} \omega 7 \mathrm{c}\right.$ and/or iso- $\left.\mathrm{C}_{15: 0} 2-\mathrm{OH}\right)$ as the major fatty acids. The DNA G +C content was 48.3 mol\%. Phylogenetic trees based on 16S rRNA gene sequences showed that strain DF $-42^{\top}$ falls within the evolutionary radiation enclosed by the genus Photobacterium. Strain DF- $42^{\top}$ exhibited $16 \mathrm{~S}$ rRNA gene sequence similarity values of 93.8-97.9\% to the type strains of Photobacterium species with validly published names. DNADNA relatedness data and differential phenotypic properties made it possible to categorize strain DF $-42^{\top}$ as representing a species that is separate from previously described Photobacterium species. The name Photobacterium lutimaris sp. nov. is proposed, with strain DF- $42^{\top}(=\mathrm{KCTC}$ $12723^{\top}=\mathrm{JCM} 13586^{\top}$ ) as the type strain.
\end{abstract}

A member of the Gammaproteobacteria, the genus Photobacterium was first proposed by Beijerinck (1889). The genus is currently composed of the following species: Photobacterium phosphoreum (Beijerinck, 1889; Reichelt \& Baumann, 1973), P. leiognathi (Boisvert et al., 1967), P. fischeri (Beijerinck, 1889; Reichelt \& Baumann, 1973), $P$. angustum (Reichelt et al., 1976), P. damselae (Smith et al., 1991), P. iliopiscarium (Onarheim et al., 1994; Urakawa et al., 1999), P. profundum (Nogi et al., 1998), P. indicum (Xie \& Yokota, 2004), P. rosenbergii (Thompson et al., 2005), $P$. lipolyticum (Yoon et al., 2005), P. frigidiphilum (Seo et al., 2005a), P. aplysiae (Seo et al., 2005b), P. ganghwense (Park et al., 2006) and P. halotolerans (Rivas et al., 2006). Here, we report on the taxonomic characterization of a Photobacterium-like bacterial strain, DF- $42^{\mathrm{T}}$, which was isolated from a tidal flat sediment in Saemankum, Korea.

Strain DF- $42^{\mathrm{T}}$ was isolated by the usual dilution-plating technique on marine agar 2216 (MA; Difco) at $30^{\circ} \mathrm{C}$. Growth at various temperatures from 4 to $45^{\circ} \mathrm{C}$ was measured on MA and tolerance of various $\mathrm{NaCl}$ concentrations was measured in marine broth 2216 (MB; Difco). Growth in the absence of $\mathrm{NaCl}$ was investigated on $\mathrm{R} 2 \mathrm{~A}$ agar (Difco) and trypticase soy agar prepared according to the formula of the Difco medium except that no $\mathrm{NaCl}$ was used. Optimal $\mathrm{pH}$ and $\mathrm{pH}$ range for growth were determined in $\mathrm{MB}$ that was adjusted to various $\mathrm{pH}$ values $(\mathrm{pH} 4.5-9.0$ at intervals of $0.5 \mathrm{pH}$ units) after autoclaving. Growth under

The GenBank/EMBL/DDBJ accession number for the 16S rRNA gene sequence of strain DF- $42^{\top}$ is DQ534014. anaerobic conditions was determined after incubation in an anaerobic chamber on MA and on MA supplemented with nitrate, both of which had been prepared anaerobically using nitrogen. The cell morphology was examined by light microscopy (Nikon E600) and transmission electron microscopy. The presence of flagella was determined by transmission electron microscopy using cells from exponentially growing cultures. The Gram reaction was determined by using the bioMérieux Gram stain kit according to the manufacturer's instructions. Catalase and oxidase activities and hydrolysis of casein and starch were determined as described by Cowan \& Steel (1965). Hydrolysis of hypoxanthine, tyrosine and xanthine was examined on MA with the substrate concentrations described previously (Cowan \& Steel, 1965). Hydrolysis of aesculin, gelatin and urea and nitrate reduction were studied as described by Lanyi (1987) with the modification that artificial seawater (containing $23.6 \mathrm{~g} \mathrm{NaCl}, 0.64 \mathrm{~g} \mathrm{KCl}, 4.53 \mathrm{~g} \mathrm{MgCl}_{2} .6 \mathrm{H}_{2} \mathrm{O}$, $5.94 \mathrm{~g} \mathrm{MgSO}_{4} .7 \mathrm{H}_{2} \mathrm{O}$ and $1.3 \mathrm{~g} \mathrm{CaCl}_{2} .2 \mathrm{H}_{2} \mathrm{O}$ per litre distilled water; Bruns et al., 2001) was used for the preparation of media. Hydrolysis of Tweens 20, 40, 60 and 80 was determined as described by Cowan \& Steel (1965) with the modification that artificial seawater was used for the preparation of media. Acid production from carbohydrates was determined as described by Leifson (1963). Utilization of various substrates for growth was determined as described by Yurkov et al. (1994). The API ZYM system (bioMérieux) was used to determine enzyme activity. The API 20E system (bioMérieux) was used to examine other physiological and biochemical properties. Antibiotic sensitivity was tested by spreading a bacterial suspension on MA 
Table 1. Differential phenotypic characteristics of Photobacterium species

Species: 1, P. lutimaris sp. nov. (strain DF-42 ${ }^{\mathrm{T}}$ ); 2, P. angustum (data from Baumann \& Baumann, 1984; Nogi et al., 1998); 3, P. damselae (Smith et al., 1991; Gauthier et al., 1995; Nogi et al., 1998); 4, P. iliopiscarium (Onarheim et al., 1994); 5, P. leiognathi (Baumann \& Baumann, 1984; Nogi et al., 1998); 6, P. phosphoreum (Reichelt \& Baumann, 1973; Baumann \& Baumann, 1984; Nogi et al., 1998); 7, P. profundum (Nogi et al., 1998); 8, P. indicum (Johnson \& Weisrock, 1969; Xie \& Yokota, 2004); 9, P. lipolyticum (Yoon et al., 2005); 10, P. frigidiphilum (Seo et al., 2005a); 11, P. aplysiae (Seo et al., 2005b); 12, P. rosenbergii (Thompson et al., 2005); 13, P. ganghwense (Park et al., 2006); 14, P. halotolerans (Rivas et al., 2006). +, Positive; -, negative; V, variable; W, weak; ND, no data available. Data in parentheses are for type strains.

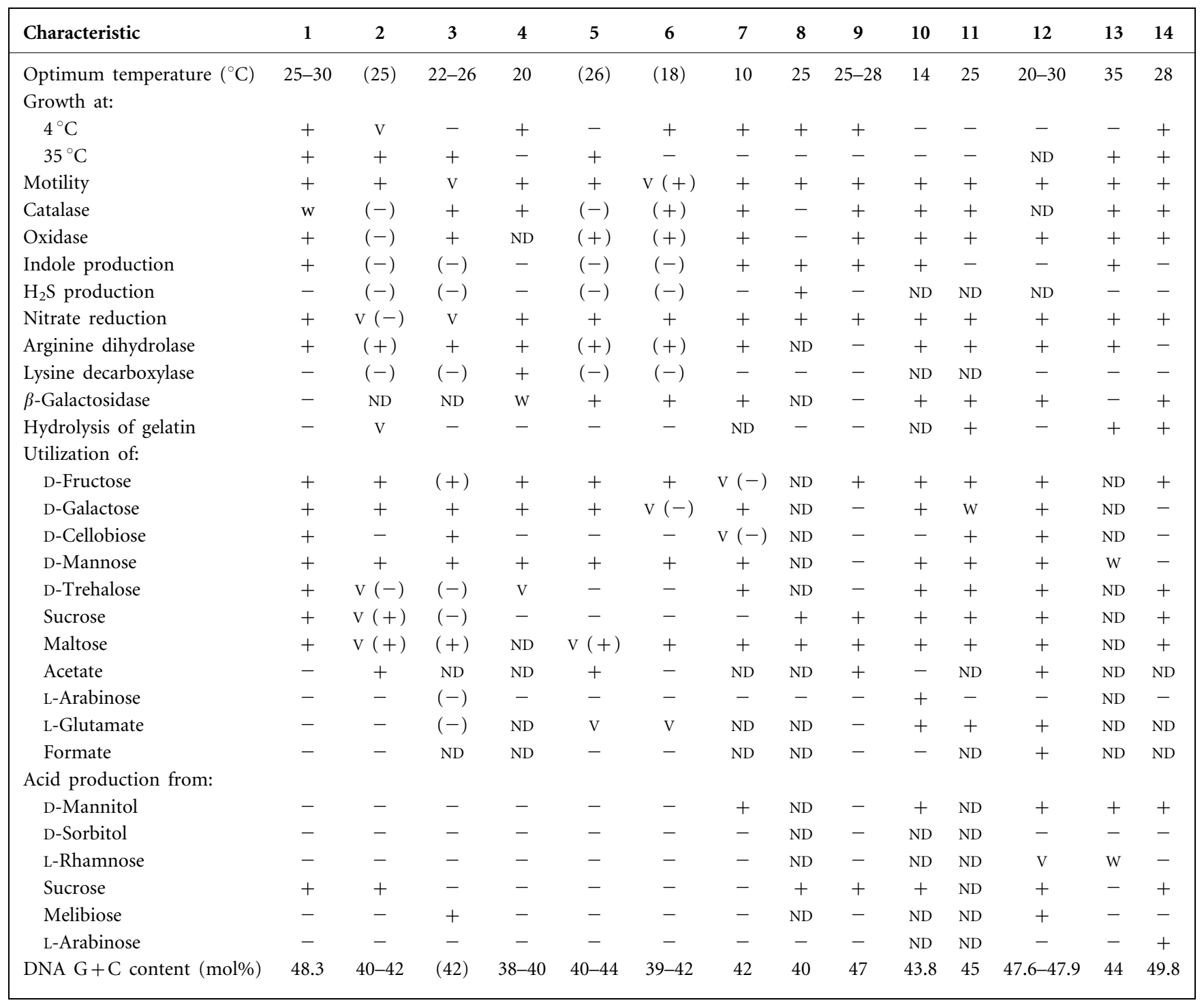

and applying discs impregnated with the following antibiotics (amount per disc): ampicillin $(10 \mu \mathrm{g})$, carbenicillin $(100 \mu \mathrm{g})$, cephalothin $(30 \mu \mathrm{g})$, chloramphenicol $(100 \mu \mathrm{g})$, gentamicin $(30 \mu \mathrm{g})$, lincomycin $(15 \mu \mathrm{g})$, kanamycin $(30 \mu \mathrm{g})$, neomycin $(30 \mu \mathrm{g})$, novobiocin $(5 \mu \mathrm{g})$, oleandomycin $(15 \mu \mathrm{g})$, penicillin $\mathrm{G}(20 \mathrm{U})$, polymyxin $\mathrm{B}$ $(100 \mathrm{U})$, streptomycin $(50 \mu \mathrm{g})$ and tetracycline $(30 \mu \mathrm{g})$.

Cell biomass of strain DF- $42^{\mathrm{T}}$ for DNA extraction and for respiratory lipoquinone analysis was obtained by cultivation for 3 days in $\mathrm{MB}$ at $30^{\circ} \mathrm{C}$. Chromosomal DNA was isolated and purified according to the method of Yoon et al. (1996). $16 \mathrm{~S}$ rRNA gene amplification was performed according to a method described previously using two universal primers (Yoon et al., 1998). Sequencing of the amplified 16S rRNA gene was performed as described by Yoon et al. (2003). Alignment of sequences was carried out with the CLUSTAL W program (Thompson et al., 1994) and gaps at the 5' and 3' ends of the alignment were omitted from further analysis. Evolutionary distances were calculated using the Kimura two-parameter correction with CLUSTAL W (Thompson et al., 1994). A phylogenetic tree was constructed by using the 


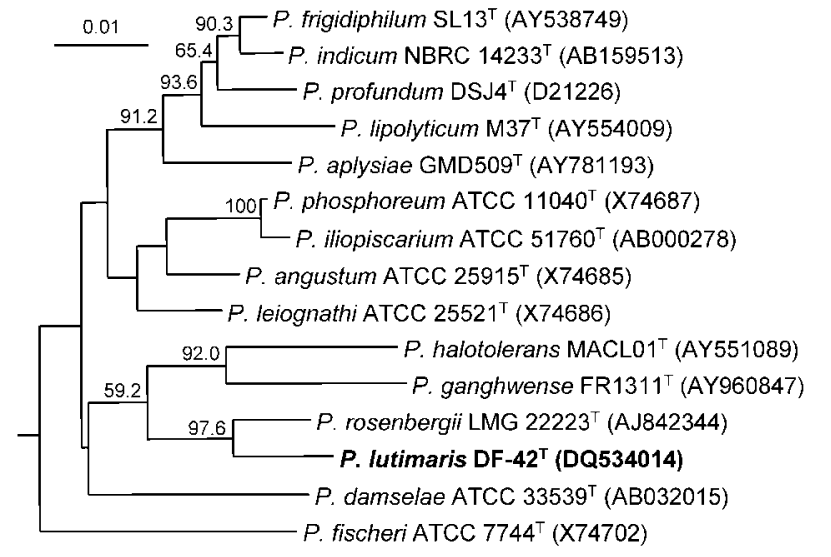

Fig. 1. Neighbour-joining tree showing the phylogenetic positions of strain DF- $42^{\top}$ and other related taxa, based on $16 \mathrm{~S}$ rRNA gene sequences. Bootstrap values are expressed as percentages of 1000 replications; only values greater than $50 \%$ are shown. Escherichia coli ATCC $11775^{\top}$ (GenBank accession no. X80725) was used as an outgroup (not shown). Bar, 0.01 substitutions per nucleotide position.

neighbour-joining method (Saitou \& Nei, 1987) on the basis of distance matrix data. The reliability of groupings was assessed by 1000 bootstrap resamplings of the neighbourjoining dataset by using CLUSTAL W. DNA-DNA hybridization was determined by the microplate hybridization method (Ezaki et al., 1989) using photobiotin-labelled DNA probes. $P$. rosenbergii LMG $22223^{\mathrm{T}}$ was used as a reference strain for DNA-DNA hybridization and was obtained from the Laboratorium voor Microbiologie, Universiteit Gent (LMG), Brussels, Belgium. Isoprenoid quinones were extracted according to the method of Komagata \& Suzuki (1987) and analysed using reversedphase HPLC and a YMC ODS-A $(250 \times 4.6 \mathrm{~mm})$ column. For fatty acid methyl ester analysis, cell mass of strain DF$42^{\mathrm{T}}$ was harvested from MA plates after incubation for 3 days at $30^{\circ} \mathrm{C}$. Fatty acid methyl esters were extracted and prepared according to the standard protocol of the MIDI/ Hewlett Packard Microbial Identification System (Sasser, 1990). The DNA G+C content was determined by the method of Tamaoka \& Komagata (1984) with the modification that the DNA was hydrolysed and the resultant nucleotides were analysed by reversed-phase HPLC.

Morphological, cultural, physiological and biochemical characteristics of strain DF- $42^{\mathrm{T}}$ are given in the species description or are shown in Table 1. The almost-complete $16 \mathrm{~S}$ rRNA gene sequence of strain DF- $42^{\mathrm{T}}$ determined in this study comprised 1508 nucleotides. Comparative $16 \mathrm{~S}$ rRNA gene sequence analysis revealed that strain $\mathrm{DF}-42^{\mathrm{T}}$ was phylogenetically most closely affiliated to the genus Photobacterium (Fig. 1). In the phylogenetic tree based on the neighbour-joining algorithm, strain DF- $42^{\mathrm{T}}$ fell within the radiation of the cluster comprising Photobacterium species, joining $P$. rosenbergii LMG $22223^{\mathrm{T}}$ at a bootstrap
Table 2. Comparison of cellular fatty acid compositions of strain DF- $42^{\top}$ and some other Photobacterium species

Species/strains: 1, P. lutimaris sp. nov. DF- $42^{\mathrm{T}} ; 2$, P. rosenbergii (data from Thompson et al., 2005); 3, P. lipolyticum M37 ${ }^{\mathrm{T}}$ (Yoon et al., 2005); 4, P. ganghwense KCTC $12328^{\mathrm{T}}$ (Park et al., 2006); 5, P. halotolerans LMG $22194^{\mathrm{T}}$ (Rivas et al., 2006). Values are percentage of total fatty acids. -, Not detected or not described. ECL, Equivalent chain-length.

\begin{tabular}{|c|c|c|c|c|c|}
\hline Fatty acid & 1 & 2 & 3 & 4 & 5 \\
\hline \multicolumn{6}{|l|}{ Straight-chain fatty acids } \\
\hline $\mathrm{C}_{12: 0}$ & 2.4 & 2 & - & 3.4 & 5.9 \\
\hline $\mathrm{C}_{14: 0}$ & 2.4 & $3-4$ & 3.8 & 3.6 & 1.0 \\
\hline $\mathrm{C}_{15: 0}$ & 2.1 & $1-2$ & - & - & - \\
\hline $\mathrm{C}_{16: 0}$ & 13.1 & $10-15$ & 25.9 & 21.1 & 21.2 \\
\hline $\mathrm{C}_{17: 0}$ & - & 1 & - & - & - \\
\hline \multicolumn{6}{|l|}{ Branched fatty acids } \\
\hline iso- $\mathrm{C}_{13: 0}$ & - & 1 & - & - & - \\
\hline iso- $\mathrm{C}_{15: 0}$ & 5.0 & $2-4$ & - & - & - \\
\hline iso- $\mathrm{C}_{17: 0}$ & 1.8 & $3-6$ & - & - & - \\
\hline iso- $\mathrm{C}_{17: 1} \omega 9 c$ & 1.8 & $1-2$ & & - & - \\
\hline iso- $\mathrm{C}_{16: 0}$ & - & - & - & - & 1.0 \\
\hline \multicolumn{6}{|l|}{ Unsaturated fatty acids } \\
\hline $\mathrm{C}_{16: 1} \omega 9 c$ & - & - & - & - & 2.5 \\
\hline $\mathrm{C}_{17: 1} \omega 8 c$ & - & 1 & - & - & - \\
\hline $\mathrm{C}_{18: 1} \omega 7 c$ & 13.0 & $17-19$ & 5.9 & 29.6 & 19.9 \\
\hline $\mathrm{C}_{16: 1} \omega 7 c$ alcohol & 1.2 & 1 & - & - & - \\
\hline \multicolumn{6}{|l|}{ Hydroxy fatty acids } \\
\hline $\mathrm{C}_{12: 0} 3-\mathrm{OH}$ & 2.6 & $2-3$ & 4.0 & 2.1 & 6.6 \\
\hline iso- $\mathrm{C}_{15: 0} 3-\mathrm{OH}$ & - & 1 & - & - & - \\
\hline Unknown ECL 12.484 & - & - & - & - & 1.0 \\
\hline \multicolumn{6}{|l|}{ Summed features ${ }^{*}$} \\
\hline 2 & 3.0 & $2-3$ & - & 2.7 & 3.0 \\
\hline 3 & 43.3 & $41-44$ & 51.3 & 27.8 & 32.6 \\
\hline
\end{tabular}

${ }^{\star}$ Summed features represent groups of two or three fatty acids that could not be separated by GLC with the MIDI system. Summed feature 2 contained $\mathrm{C}_{14: 0} 3-\mathrm{OH}$, iso- $\mathrm{C}_{16: 1} \mathrm{I}$, an unidentified fatty acid with an equivalent chain-length of 10.928 and/or $\mathrm{C}_{12: 0}$ ALDE. Summed feature 3 contained $\mathrm{C}_{16: 1} \omega 7 c$ and/or iso- $\mathrm{C}_{15: 0} 2-\mathrm{OH}$.

resampling value of $97.6 \%$ (Fig. 1). Strain DF- $42^{\mathrm{T}}$ exhibited $16 \mathrm{~S}$ rRNA gene sequence similarity values of $97.9 \%$ to $P$. rosenbergii LMG $22223^{\mathrm{T}}$ and $93.8-96.0 \%$ with respect to the type strains of the other Photobacterium species (Fig. 1). The mean DNA-DNA relatedness level between strain DF- $42^{\mathrm{T}}$ and $P$. rosenbergii LMG $22223^{\mathrm{T}}$ was $21.6 \%$ when their DNAs were used individually as labelled DNA probes for crosshybridization. The results obtained from chemotaxonomic analyses were consistent with the phylogenetic affiliation of strain DF- $42^{\mathrm{T}}$ to the genus Photobacterium. Strain DF- $42^{\mathrm{T}}$ contained Q-8 as the predominant ubiquinone at a peak area ratio of approximately $90 \%$. The cellular fatty acid profile of strain DF- $42^{\mathrm{T}}$ is shown in Table 2, together with those of phylogenetically related Photobacterium species. The fatty acid profile was characterized by the presence of 
large amounts of straight-chain, branched, unsaturated and hydroxy fatty acids; the major components were $\mathrm{C}_{16: 0}$, $\mathrm{C}_{18: 1} \omega 7 c$ and summed feature $3\left(\mathrm{C}_{16: 1} \omega 7 c\right.$ and/or iso- $\mathrm{C}_{15: 0}$ 2-OH). This fatty acid profile is similar to those of other Photobacterium species, although there were differences in the proportions of some fatty acids (Table 2). Some fatty acids that were detected in amounts of more than $1 \%$ in $P$. rosenbergii strains, including $\mathrm{C}_{17: 0}$, iso- $\mathrm{C}_{13: 0}, \mathrm{C}_{17: 1} \omega 8 \mathrm{c}$ and iso- $\mathrm{C}_{15: 0} 3-\mathrm{OH}$, were not found in strain DF- $42^{\mathrm{T}}$.

Strain DF- $42^{\mathrm{T}}$ was distinguished from other Photobacterium species by differences in some phenotypic properties, as shown in Table 1. Particularly, strain DF- $42^{\mathrm{T}}$ differed from its closest phylogenetic neighbour, $P$. rosenbergii, in several phenotypic properties, including growth at $4{ }^{\circ} \mathrm{C}$, indole production, $\beta$-galactosidase activity, utilization of some substrates and acid production from some substrates. The phylogenetic distinctiveness and DNA-DNA relatedness data, together with differential phenotypic properties, show that strain $\mathrm{DF}-42^{\mathrm{T}}$ is distinct from recognized Photobacterium species (Wayne et al., 1987; Stackebrandt \& Goebel, 1994). Therefore, on the basis of the data presented, strain DF- $42^{\mathrm{T}}$ should be classified in the genus Photobacterium as the type strain of a novel species, for which the name Photobacterium lutimaris sp. nov. is proposed.

\section{Description of Photobacterium lutimaris sp. nov.}

Photobacterium lutimaris (lu.ti.ma' ris. L. n. lutum mud; L. gen. n. maris of the sea; N.L. gen. n. lutimaris of mud of the sea).

Cells are Gram-negative, oval-shaped and 0.9-1.3 × 1.5$2.1 \mu \mathrm{m}$. Motile by means of a single polar flagellum. Colonies on MA are circular to slightly irregular, flat, smooth, glistening, pale yellow in colour and $2.0-4.0 \mathrm{~mm}$ in diameter after 3 days incubation at $30^{\circ} \mathrm{C}$. Not bioluminescent. Growth occurs under anaerobic conditions on MA and on MA with nitrate. Growth occurs at 4 and $41^{\circ} \mathrm{C}$ with an optimum temperature of $25-30{ }^{\circ} \mathrm{C}$. Optimal $\mathrm{pH}$ for growth is 7.5-8.5; growth occurs weakly at $\mathrm{pH} 5.0$, but not at $\mathrm{pH} 4.5$. Optimal growth occurs in the presence of $2-3 \%$ $(\mathrm{w} / \mathrm{v}) \mathrm{NaCl}$; growth occurs in the presence of $6 \%(\mathrm{w} / \mathrm{v})$ $\mathrm{NaCl}$, but no growth occurs without $\mathrm{NaCl}$ or in the presence of $>7 \% \mathrm{NaCl}$. Aesculin, starch and Tweens 20, 40, 60 and 80 are hydrolysed. Tyrosine is hydrolysed weakly. Urea, hypoxanthine, xanthine and casein are not hydrolysed. Ornithine decarboxylase and tryptophan deaminase are absent. Using the API ZYM system (bioMérieux), alkaline phosphatase, esterase (C4), esterase lipase (C8), leucine arylamidase, cystine arylamidase, acid phosphatase and naphthol-AS-BI-phosphohydrolase are present, but lipase (C14), valine arylamidase, trypsin, $\alpha$-chymotrypsin, $\alpha$ galactosidase, $\beta$-glucuronidase, $\alpha$-glucosidase, $\beta$-glucosidase, $\quad N$-acetyl- $\beta$-glucosaminidase, $\alpha$-mannosidase and $\alpha$-fucosidase are absent. D-Glucose, D-xylose, citrate, succinate, L-malate, salicin and pyruvate are utilized as sole carbon and energy sources, but benzoate is not. Acid is produced from myo-inositol, D-xylose, D-ribose, D-fructose and D-cellobiose, but not from D-melezitose, D-glucose, Dgalactose, D-mannose, lactose, maltose, D-trehalose or D-raffinose. Susceptible to polymyxin B, streptomycin, penicillin G, chloramphenicol, ampicillin, cephalothin, gentamicin, novobiocin, kanamycin, lincomycin, neomycin and carbenicillin, but not to oleandomycin or tetracycline. The major cellular fatty acids are $\mathrm{C}_{16: 0}, \mathrm{C}_{18: 1} \omega 7 c$ and summed feature $3\left(\mathrm{C}_{16: 1} \omega 7 c\right.$ and/or iso- $\left.\mathrm{C}_{15: 0} 2-\mathrm{OH}\right)$. The predominant ubiquinone is Q-8. The DNA G $+\mathrm{C}$ content of the type strain is $48.3 \mathrm{~mol} \%$.

The type strain, DF- $42^{\mathrm{T}}\left(=\mathrm{KCTC} 12723^{\mathrm{T}}=\mathrm{JCM} 13586^{\mathrm{T}}\right)$, was isolated from a tidal flat sediment at Saemankum, Korea.

\section{Acknowledgements}

This work was supported by the 21C Frontier Program of Microbial Genomics and Applications (grant MG05-0401-2-0) from the Ministry of Science and Technology (MOST) of the Republic of Korea.

\section{References}

Baumann, P. \& Baumann, L. (1984). Genus Photobacterium Beijerinck 1889, 401 ${ }^{\mathrm{AL}}$. In Bergey's Manual of Systematic Bacteriology, vol. 1, pp. 539-545. Edited by N. R. Krieg \& J. G. Holt. Baltimore: Williams \& Wilkins.

Beijerinck, M. W. (1889). Le Photobacterium luminosum, bactérie lumineuse de la Mer du Nord. Arch Neerl Sci Exactes Nat 23, 401427 (in French).

Boisvert, H., Chatelain, R. \& Bassot, J.-M. (1967). Etude d'un Photobacterium isolé de l'organe lumineux de poissons Leiognathidae. Ann Inst Pasteur (Paris) 112, 520-524 (in French).

Bruns, A., Rohde, M. \& Berthe-Corti, L. (2001). Muricauda ruestringensis gen. nov., sp. nov., a facultatively anaerobic, appendaged bacterium from German North Sea intertidal sediment. Int J Syst Evol Microbiol 51, 1997-2006.

Cowan, S. T. \& Steel, K. J. (1965). Manual for the Identification of Medical Bacteria. London: Cambridge University Press.

Ezaki, T., Hashimoto, Y. \& Yabuuchi, E. (1989). Fluorometric deoxyribonucleic acid-deoxyribonucleic acid hybridization in microdilution wells as an alternative to membrane filter hybridization in which radioisotopes are used to determine genetic relatedness among bacterial strains. Int J Syst Bacteriol 39, 224-229.

Gauthier, G., Ruimy, L. R., Breittmayer, V., Nicolas, J. L., Gauthier, M. \& Christen, R. (1995). Small-subunit rRNA sequences and whole DNA relatedness concur for the reassignment of Pasteurella piscicida (Snieszko et al.) Janssen and Surgalla to the genus Photobacterium as Photobacterium damsela subsp. piscicida comb. nov. Int J Syst Bacteriol 45, 139-144.

Johnson, R. M. \& Weisrock, W. P. (1969). Hyphomicrobium indicum sp. nov. (Hyphomicrobiaceae Douglas). Int J Syst Bacteriol 19, 295-307.

Komagata, K. \& Suzuki, K. (1987). Lipids and cell-wall analysis in bacterial systematics. Methods Microbiol 19, 161-203.

Lanyi, B. (1987). Classical and rapid identification methods for medically important bacteria. Methods Microbiol 19, 1-67.

Leifson, E. (1963). Determination of carbohydrate metabolism of marine bacteria. J Bacteriol 85, 1183-1184. 
Nogi, Y., Masui, N. \& Kato, C. (1998). Photobacterium profundum sp. nov., a new, moderately barophilic bacterial species isolated from a deep-sea sediment. Extremophiles 2, 1-7.

Onarheim, A. M., Wiik, R., Burghardt, J. \& Stackebrandt, E. (1994). Characterization and identification of two Vibrio species indigenous to the intestine of fish in cold sea water; description of Vibrio iliopiscarius sp. nov. Syst Appl Microbiol 17, 370-379.

Park, Y. D., Baik, K. S., Seong, C. N., Bae, K. S., Kim, S. \& Chun, J. (2006). Photobacterium ganghwense sp. nov., a halophilic bacterium isolated from sea water. Int J Syst Evol Microbiol 56, 745-749.

Reichelt, J. L. \& Baumann, P. (1973). Taxonomy of the marine, luminous bacteria. Arch Mikrobiol 94, 283-330.

Reichelt, J. L., Baumann, P. \& Baumann, L. (1976). Study of genetic relationships among marine species of the genera Beneckea and Photobacterium. Arch Microbiol 110, 101-120.

Rivas, R., García-Fraile, P., Mateos, P. F., Martínez-Molina, E. \& Velázquez, E. (2006). Photobacterium halotolerans sp. nov., isolated from Lake Martel in Spain. Int J Syst Evol Microbiol 56, 1067-1071.

Saitou, N. \& Nei, M. (1987). The neighbor-joining method: a new method for reconstructing phylogenetic trees. Mol Biol Evol 4, 406-425.

Sasser, M. (1990). Identification of bacteria by gas chromatography of cellular fatty acids. Technical Note 101. Newark, DE: MIDI.

Seo, H. J., Bae, S. S., Lee, J. H. \& Kim, S. J. (2005a). Photobacterium frigidiphilum sp. nov., a psychrophilic, lipolytic bacterium isolated from deep-sea sediments of Edison Seamount. Int J Syst Evol Microbiol 55, 1661-1666.

Seo, H. J., Bae, S. S., Yang, S. H., Lee, J. H. \& Kim, S. J. (2005b). Photobacterium aplysiae sp. nov., a lipolytic marine bacterium isolated from eggs of the sea hare Aplysia kurodai. Int J Syst Evol Microbiol 55, 2293-2296.

Smith, S. K., Sutton, D. C., Fuerst, J. A. \& Reichelt, J. L. (1991). Evaluation of the genus Listonella and reassignment of Listonella damsela (Love et al.) MacDonell and Colwell to the genus Photobacterium as Photobacterium damsela comb. nov. with an emended description. Int J Syst Bacteriol 41, 529-534.

Stackebrandt, E. \& Goebel, B. M. (1994). Taxonomic note: a place for DNA-DNA reassociation and $16 \mathrm{~S}$ rRNA sequence analysis in the present species definition in bacteriology. Int J Syst Bacteriol 44, 846-849.
Tamaoka, J. \& Komagata, K. (1984). Determination of DNA base composition by reverse-phase high-performance liquid chromatography. FEMS Microbiol Lett 25, 125-128.

Thompson, F. L., Thompson, C. C., Naser, S., Hoste, B., Vandemeulebroecke, K., Munn, C., Bourne, D. \& Swings, J. (2005). Photobacterium rosenbergii sp. nov. and Enterovibrio coralii sp. nov., vibrios associated with coral bleaching. Int J Syst Evol Microbiol 55, 913-917.

Urakawa, H., Kita-Tsukamoto, K. \& Ohwada, K. (1999). Reassessment of the taxonomic position of Vibrio iliopiscarius (Onarheim et al. 1994) and proposal for Photobacterium iliopiscarium comb. nov. Int J Syst Bacteriol 49, 257-260.

Wayne, L. G., Brenner, D. J., Colwell, R. R., Grimont, P. A. D., Kandler, O., Krichevsky, M. I., Moore, L. H., Moore, W. E. C., Murray, R. G. E. \& other authors (1987). International Committee on Systematic Bacteriology. Report of the ad hoc committee on reconciliation of approaches to bacterial systematics. Int J Syst Bacteriol 37, 463-464.

Xie, C.-H. \& Yokota, A. (2004). Transfer of Hyphomicrobium indicum to the genus Photobacterium as Photobacterium indicum comb. nov. Int J Syst Evol Microbiol 54, 2113-2116.

Yoon, J.-H., Kim, H., Kim, S.-B., Kim, H.-J., Kim, W. Y., Lee, S. T., Goodfellow, M. \& Park, Y.-H. (1996). Identification of Saccharomonospora strains by the use of genomic DNA fragments and rRNA gene probes. Int J Syst Bacteriol 46, 502-505.

Yoon, J.-H., Lee, S. T. \& Park, Y.-H. (1998). Inter- and intraspecific phylogenetic analysis of the genus Nocardioides and related taxa based on 16S rDNA sequences. Int J Syst Bacteriol 48, 187-194.

Yoon, J.-H., Kim, I.-G., Kang, K. H., Oh, T.-K. \& Park, Y.-H. (2003). Alteromonas marina sp. nov., isolated from sea water of the East Sea in Korea. Int J Syst Evol Microbiol 53, 1625-1630.

Yoon, J. H., Lee, J. K., Kim, Y. O. \& Oh, T. K. (2005). Photobacterium lipolyticum sp. nov., a bacterium with lipolytic activity isolated from the Yellow Sea in Korea. Int J Syst Evol Microbiol 55, 335-339.

Yurkov, V., Stackebrandt, E., Holmes, A., Fuerst, J. A., Hugenholtz, P., Golecki, J., Gad'on, N., Gorlenko, V. M., Kompantseva, E. I. \& Drews, G. (1994). Phylogenetic positions of novel aerobic, bacteriochlorophyll a-containing bacteria and description of Roseococcus thiosulfatophilus gen. nov., sp. nov., Erythromicrobium ramosum gen. nov., sp. nov., and Erythrobacter litoralis sp. nov. Int J Syst Bacteriol 44, 427-434. 